\title{
Southern black widow Latrodectus mactans (Fabricius) (Arachnida: Araneae: Theridiidae) ${ }^{1}$
}

\author{
Amanda Eiden and Phillip E. Kaufman ${ }^{2}$
}

\section{Introduction}

The Southern black widow spider, Latrodectus mactans (Fabricius), is a venomous spider found throughout the southeastern United States. Widow spiders received their name from the belief that they would kill and consume their mate following copulation. However, the practice was mainly observed in laboratory settings under crowded conditions. It is believed that sexual cannibalism within the widow species in natural settings is more associated with the male's physical inability to escape rather than the female's interest in consuming him (Breene and Sweet 1985).

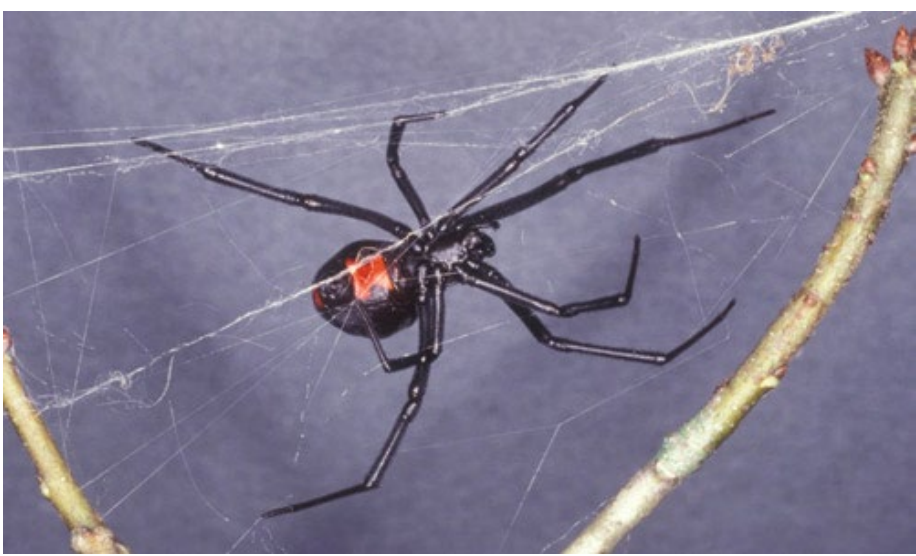

Figure 1. Adult female Southern black widow, Latrodectus mactans (Fabricius).

Credits: James L. Castner.

\section{Synonymy}

Aranea mactans Fabricius, 1775

Latrodectus schuchii C. L. Koch, 1836

Latrodectus menavodi Vinson, 1863

Latrodectus cinctus Blackwall, 1865

Latrodectus hasselti Thorell, 1870

Latrodectus hasselti indicus Simon, 1897

Latrodectus hasselti elegans Thorell, 1898

Latrodectus hahli Dahl, 1902

Latrodectus mactans insularis Dahl, 1902

Latrodectus luzonicus Dahl, 1902

Latrodectus mactans insularis Dahl, 1902

Latrodectus mactans insularis lunifer Dahl, 1902

Latrodectus renivulvatus Dahl, 1902

Latrodectus sagittifer Dahl, 1902

Latrodectus stuhlmanni Dahl, 1902

1. This document is EENY 560, one of a series of the Entomology and Nematology Department, Florida Cooperative Extension Service, Institute of Food and Agricultural Sciences, University of Florida. Original publication date May 2013. Visit the EDIS website at http://edis.ifas.ufl.edu.

2. Amanda Eiden and Phillip E. Kaufman, associate professor/Extension entomologist, Entomology and Nematology Department, Cooperative Extension Service, Institute of Food and Agricultural Sciences, University of Florida, Gainesville, FI 32611. 
Latrodectus incertus O. P.-Cambridge, 1904

Latrodectus indistinctus O. P.-Cambridge, 1904

Latrodectus hasselti aruensis Strand, 1911

Latrodectus mactans albomaculatus Franganillo, 1930

Latrodectus albomaculatus Franganillo, 1930

Latrodectus agoyangyang Plantilla \& Mabalay, 1935

Latrodectus hasselti Gerschman \& Schiapelli, 1943

Latrodectus indistinctus karrooeensis Smithers, 1944

Latrodectus mexicanus Gonzalez, 1954

(Draney 2001)

\section{Other Species}

Latrodectus geometricus C.L. Koch: brown widow

Latrodectus bishopi Kaston: red widow

Latrodectus hesperus Chamberlain and Ivie: Western black widow

Latrodectus variolus Walckenaer: Northern black widow

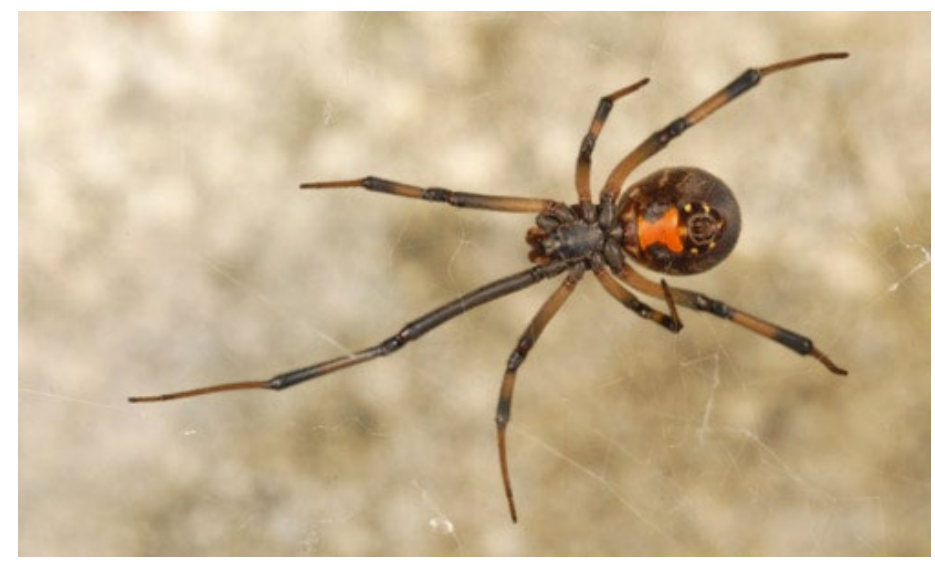

Figure 2. Adult female brown widow spider, Latrodectus geometricus (C.L. Koch).

Credits: Lyle J. Buss

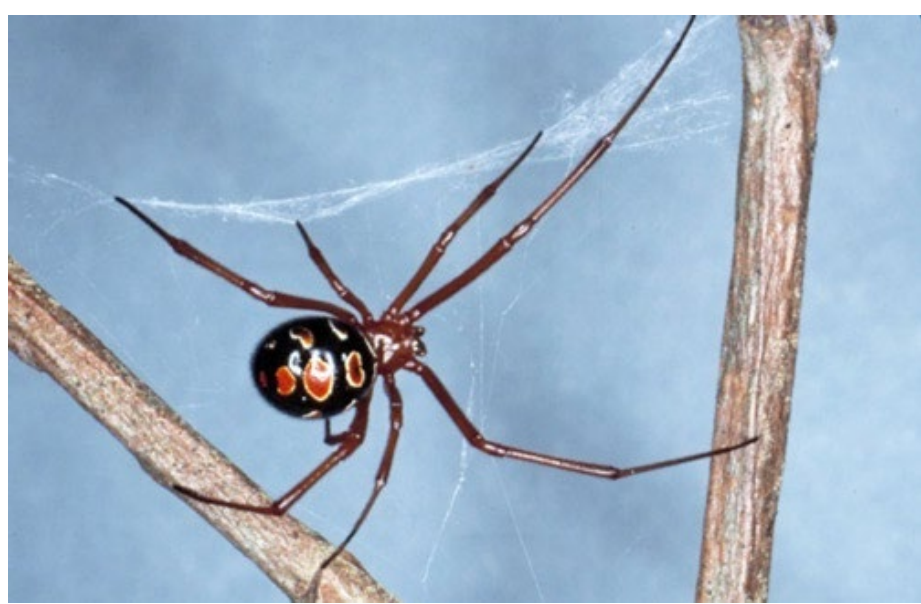

Figure 3. Dorsal view of adult red widow spider, Latrodectus bishopi (Kaston).

Credits: James L. Castner

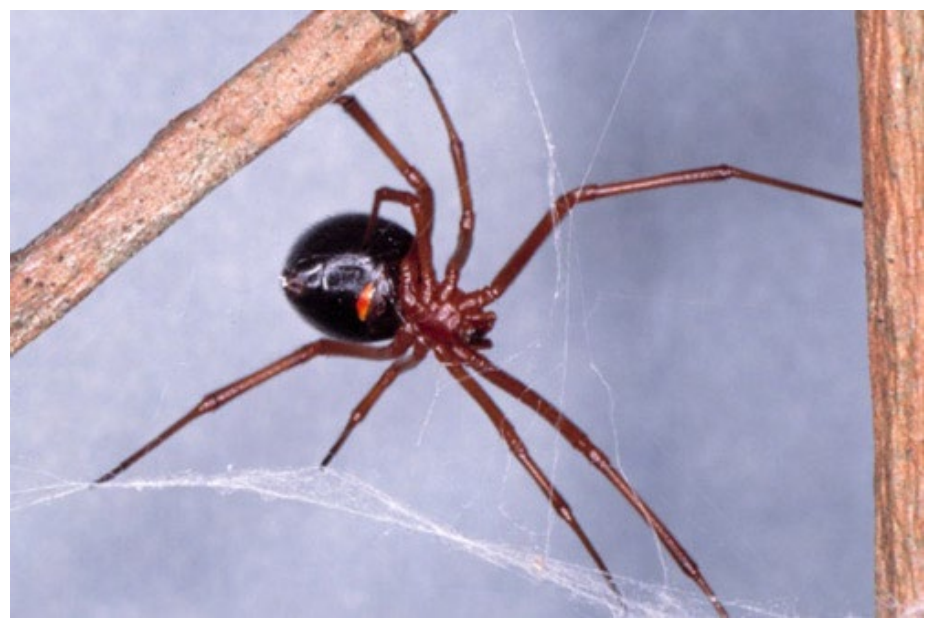

Figure 4. Ventral view of adult red widow spider, Latrodectus bishopi (Kaston).

Credits: James L. Castner

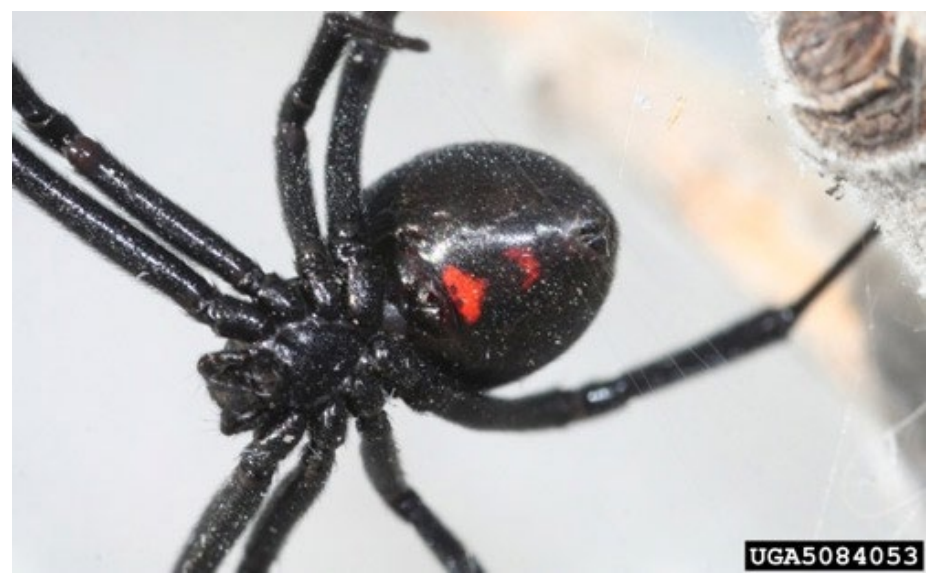

Figure 5. Adult female Western black widow, Latrodectus hesperus (Chamberlain and Ivie).

Credits: Whitney Cranshaw 


\section{Distribution}

Various species of widow spiders can be found on every continent with the exception of Antarctica (reviewed by Garb et al. 2004). In Florida, Latrodectus mactans (Southern black widow), is found as well as Latrodectus geometricus (brown widow), Latrodectus bishopi (red widow), and Latrodectus variolus (Northern black widow) (Edwards 2002). In the United States, the Southern black widow is found in the southeastern region and has been found as far north as Ohio and as far west as Texas.

\section{Description}

\section{Eggs}

The female produces a beige-colored egg sac that is approximately $1.0-1.25 \mathrm{~cm}$ in diameter and typically contains around 220 eggs, which are approximately $0.8 \mathrm{~mm}$ in diameter each (D'Amour et al. 1936, Rempel 1957, Kaston 1972).

\section{Immatures:}

Spiderlings are initially white and lack the hour-glass or spot patterns, but gain coloration and patterns more resembling adults with progressive molts (D’Amour et al. 1936).

\section{Adults}

The female Southern black widow, as described by Mote and Gray (1935), is a shiny black spider with a distinctive red hourglass on the abdomen. The Southern black widow has a complete hourglass, while the Western species' hourglass can vary from two connected triangles to separated triangles to a minimum of barely visible red blotches. The Northern widow typically has the hourglass on their abdomen but some individuals lack it completely (Kaston 1954). Females are typically 3.75 to $5 \mathrm{~cm}$ long including the leg span, while their bodies are $1.25 \mathrm{~cm}$ long. Male Southern black widows are smaller, typically with a $0.6 \mathrm{~cm}$ long body (Mote and Gray 1935). Male Southern black widows lack the characteristic hourglass of the female, but may have red spotting on the top or underside of the abdominal segment.

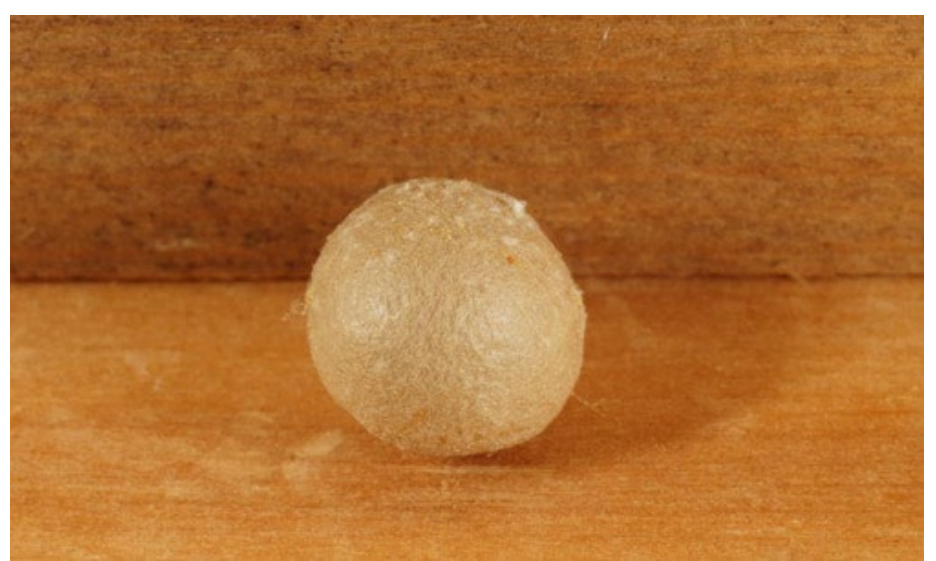

Figure 6. Egg sac of a Southern black widow, Latrodectus mactans Credits: Lyle J. Buss

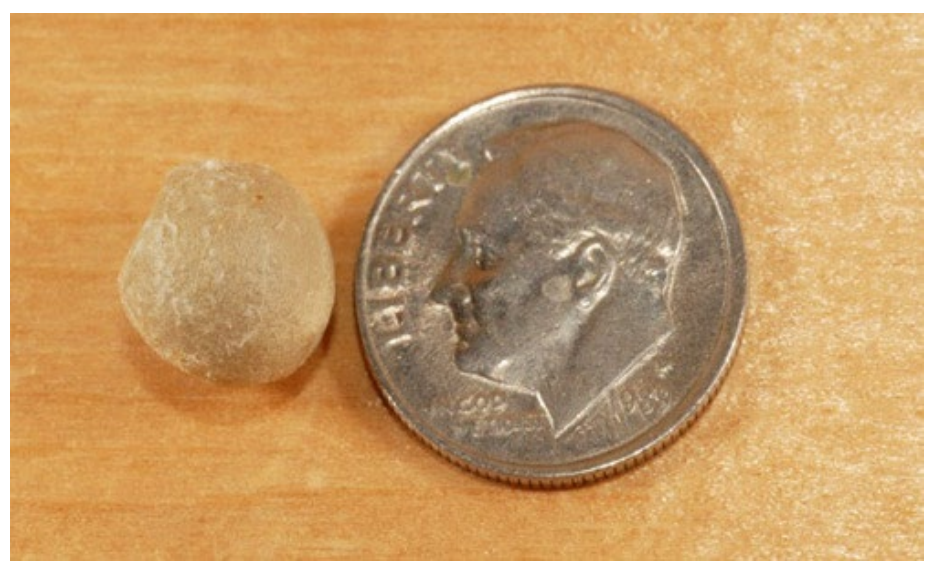

Figure 7. Egg sac of a Southern black widow, Latrodectus mactans (Fabricius). Southern black widow egg sacs are typically $1.0-1.25 \mathrm{~cm}$ across; the photo demonstrates the size in comparison to a dime. Credits: Lyle J. Buss

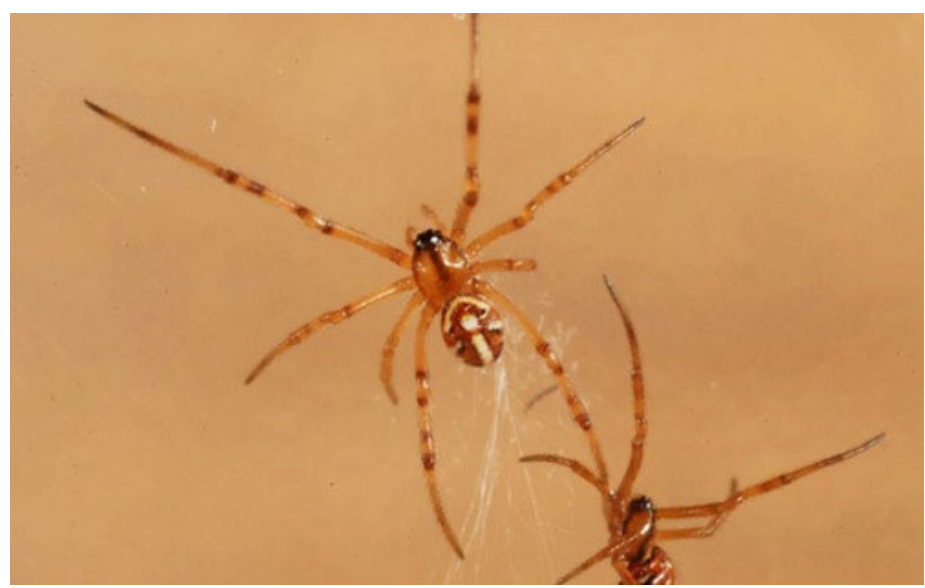

Figure 8. Dorsal view of Southern black widow spiderlings, Latrodectus mactans (Fabricius).

Credits: Lyle J. Buss 


\section{Life Cycle}

Widow spiders are well known for their potentially dangerous bite. Widows have potent venom, which contains the neurotoxin alpha-latrotoxin that causes adverse reactions in their victims (Orlova et al. 2000). The Southern black widow typically mates during the spring and summer (Kaston 1972). The egg sacs are retained within the web, and after an incubation period of one month the spiderlings emerge from the egg sac (Mote and Gray 1935). Spiderlings molt several times before reaching adulthood. The development time may be influenced by factors such as diet and temperature and may range from 26-103 days for males and 57-122 days for females (Baxter Deevey 1949). The female Southern black widow typically lives an average of 1.5 years while the male survives between two to five months.

\section{Habitat}

Typical outdoor habitats in which spiders are often found include wood and rock piles, rodent burrows, and hollow tree stumps. Indoor habitats include outhouses, garages, sheds, and basements (D'Amour et al. 1936). Although they primarily inhabit low-lying areas, their web can be found several meters from the ground (Kaston 1938).

\section{Biology}

Spiders produce a strong silk that they use to construct webs for trapping prey. Black widow webs are constructed in an erratic manner without a distinguishable pattern (Mote and Gray 1935). Black widows exposed to environmental conditions with limited food resources have been shown to design a web that captures prey at a higher frequency than a web constructed by a spider that has an abundant food supply (Zevenbergen et al. 2008). Widow spider diet includes a wide range of insects such as flies, crickets, grasshoppers, moths, beetles, and various other arthropods that become trapped in the web (Bogen and Loomis 1936).

Black widows have been documented to be beneficial for controlling some pest populations such as red imported fire ants, Solenopsis invicta Buren (Nyffeler and Sterling 1988), and harvester ants, Pogonomyrmex rugosus Emery (MacKay 1982), through predation. The colony size reduction due to black widows feeding on harvester ants was low, but when the ants were preyed upon they demonstrated behaviors such as decreased foraging that indirectly reduced populations (MacKay 1982).

Southern black widows are normally predators, but under special circumstances they can serve as prey. Wasps,

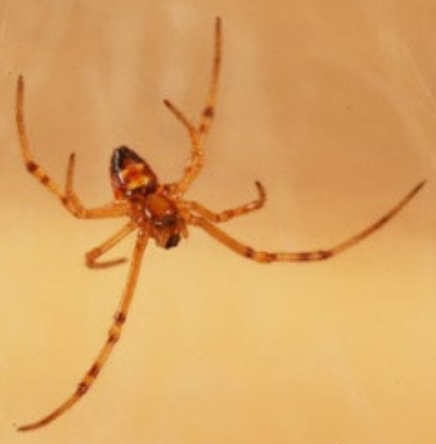

Figure 9. Ventral view of Southern black widow spiderlings, Latrodectus mactans (Fabricius).

Credits: Lyle J. Buss

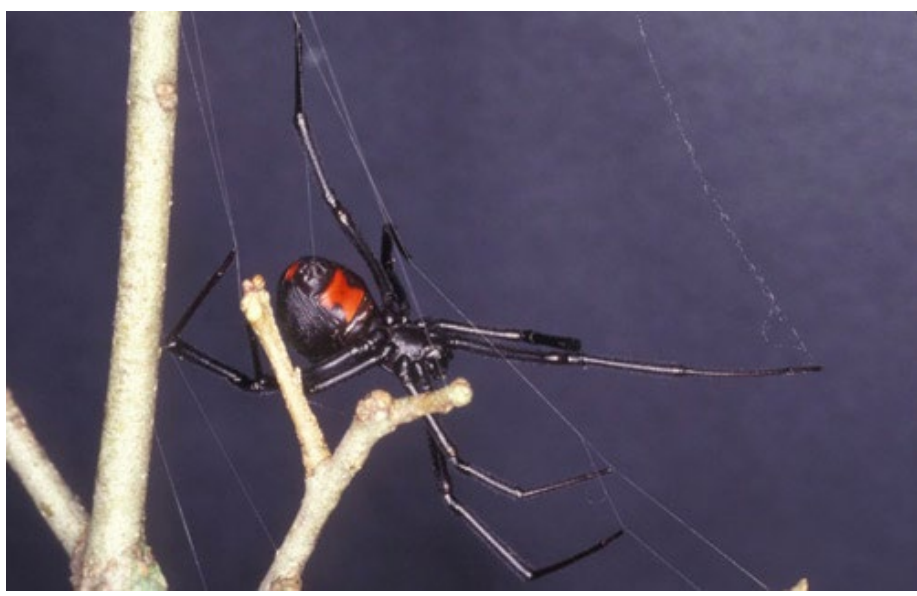

Figure 10. Adult female Southern black widow, Latrodectus mactans (Fabricius).

Credits: James L. Castner

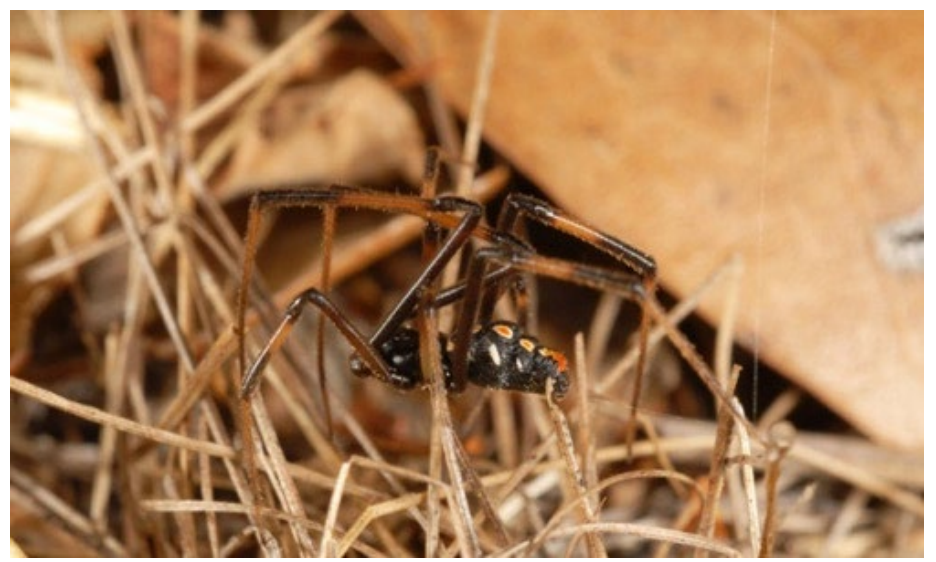

Figure 11. Adult male Southern black widow, Latrodectus mactans (Fabricius).

Credits: Lyle J. Buss

scorpions, and centipedes have been known to feed on black widows (Bogen and Loomis 1936). It is believed that brown widows, which originated in Africa, may be competing with black widows, causing a decrease in the black widow population (Vetter 2010). Brown widows have a higher reproductive rate than black widows, which may 
be contributing to the population decline. Brown widows also have more potent venom than North American black widows; however, the more timid behavior of the brown widow makes it less of a threat to people (McCrone 1964). The brown widow releases less venom when it bites and also has a tendency to curl up when disturbed, rather than attack (Vetter 2010, 2012). The displacement of black widows with a less aggressive species eventually may lead to a decrease in the annual number of bite cases.

\section{Medical Importance}

The Southern black widow spider, Latrodectus mactans (Fabricius), is a venomous spider found throughout the southeastern United States. Widow spiders received their name from the belief that they would kill and consume their mate following copulation. However, the practice was mainly observed in laboratory settings under crowded conditions. It is believed that sexual cannibalism within the widow species in natural settings is more associated with the male's physical inability to escape rather than the female's interest in consuming him (Breene and Sweet 1985).

In 2010, there were 2,168 self-reported black widow bites reported in the United States, with 892 cases treated in health care facilities (Bronstein et al. 2011). Death due to a black widow bite is rarely reported (Timms and Gibbons 1986). In the 2010 survey, over $50 \%$ of reported cases occurred in patients over 20 years of age with no deaths (Bronstein et al. 2011). Patients usually recover within 24 hours following treatment or 3 to 5 days without supportive care (Timms and Gibbons 1986, Edwards 2002). Pregnant individuals should seek medical attention immediately. Complications during pregnancy may arise due to the symptoms experienced by the expectant mother, such as headache, hypertension, cramping, muscle pain, and severe abdominal pain (Sherman et al. 2000). However, research has demonstrated that a direct effect on the fetus from the spider venom is less likely because alpha-latrotoxin is a large compound and should not cross the placental barrier (Handel et al. 1994). Wolfe et al. (2011) evaluated 97 envenomation cases during pregnancy between 2003-2007 and determined fetal risks appeared to be minimal if proper care toward the mother was administered.

Treatment for all widow bites typically includes general wound care followed by calcium gluconate, muscle relaxants, and narcotic analgesics (Timms and Gibbons 1986, Handel et al. 1994). In clinical reviews, calcium gluconate provided no relief to patients, but treatment with opioids and benzodiazepines decreased painful symptoms (Clark et al. 1992). Due to the similarity in clinical presentation, tetanus toxoid may be considered by physicians unless a spider is brought in or patient is able to positively identify a history of being bitten.

Antivenin may be used to treat patients who are experiencing a severe reaction. Antivenin is produced with antibodies in serum from horses that have been exposed to low levels of black widow venom. The antivenin may cause complications in patients who have an allergic reaction to the horse serum used in the treatment preparation (Timms and Gibbons 1986). In patients who do not have horse serum sensitivity, antivenin has been shown to be safe and effective (Offerman et al. 2011). When administered properly by a licensed medical practitioner, it has been shown to be highly effective, especially if patients are treated within the first three hours after a bite (Timms and Gibbons 1986, Clark 2001).

\section{Bite Prevention}

In nature, most bites occur while reaching under an object that the spider inhabits such as a woodpile or stones. While working in or around areas of suitable habitat for these spiders, wearing gardening gloves can help prevent envenomation. Additionally, use caution when working in sheds and barns where spiders can be found. There have been many documented cases of bites in outhouses, so searching under toilet seats before using this type of facility may prevent a bite. In indoor areas, bites frequently occur when spiders are hiding in shoes that have not been worn recently or while searching through old boxes. Shaking out clothing and shoes and using gloves while working in areas that spiders may be found such as basements or attics can help prevent a bite.

\section{Selected References}

Baerg WJ. 1923. The effects of the bite of Latrodectus mactans Fabr. The Journal of Parasitology 9: 161-169.

Baxter Deevey G. 1949. The developmental history of Latrodectus mactans (Fabr.) at different rates of feeding. American Midland Naturalist 42: 189-219.

Bogen E, Loomis RN. 1936. Poisoning poisonous spiders, an experimental investigation in the control of the black widow spider (Latrodectus mactans). California and Western Medicine 45: 31-38.

Breene RG, Sweet MH. 1985. Evidence of insemination of multiple females by the male black widow spider, 
Latrodectus mactans (Araneae, Theridiidae). Journal of Arachnology 13: 331-335.

Bronstein AC, Spyker DA, Cantilena LR, Green JL, Rumack BH, Dart C. 2011. 2010 annual report of the American Association of Poison Control Centers' national poison data system (NPDS): 28th annual report. Clinical Toxicology 49: 910-941.

Clark RF, Wethern-Kestner S, Vance MV, Gerkin R. 1992. Clinical presentation and treatment of black widow spider envenomation: A review of 1963 cases. Annals of Emergency Medicine. 21: 782-787.

Clark RF. 2001. The safety and efficacy of antivenin Latrodectus mactans. Clinical Toxicology 39: 125-127.

D’Amour FE, Becker FE, van Riper W. 1936. The black widow spider. The Quarterly Review of Biology 11: 123-160.

Draney ML. (2001). Checklist of Theridiidae (Araneae) of America north of Mexico. Department of Natural and Applied Sciences.University of Wisconsin-Green Bay.

Edwards GB. (2002). Venomous Spiders in Florida. Pest Alert. Florida Department of Agriculture and Consumer Services, Division of Plant Industry. (12 March 2013).

Garb JE, González A, Gillespie RG. 2004. The black widow spider genus Latrodectus (Araneae: Theridiidae): phylogeny, biogeography, and invasion history. Molecular Phylogenetics and Evolution 31: 1127-1142.

Handel CC, Izquierdo LA, Curet LB. 1994. Black widow spider (Latrodectus mactans) bite during pregnancy. Western Journal of Medicine 160: 261-262.

Kaston BJ. 1938. Notes on a new variety of black widow spider from southern Florida. Florida Entomologist 21: 60-61.

Kaston BJ. 1954. Is the black widow spider invading New England? Science 119: 192-193.

Kaston BJ. 1972. Comparative biology of American black widow spiders. Transactions of the San Diego Society of Natural History 16: 33-82.

MacKay WP. 1982. The effects of predation of western widow spiders (Araneae: Theridiidae) on harvester ants (Hymenoptera: Formicidae). Oecologia 53: 406-411.

McCrone JD. 1964. Comparative lethality of several Latrodectus venoms. Toxicon 2: 201-203.
Mote DC, Gray K. 1935. The black widow spider (Latrodectus mactans Fabr.). Agricultural Experiment Station Oregon State Agricultural College. Station Circular 112: 11pp. (30 May 2013).

Nyffeler M, Dean DA, Sterling WL. 1988. The southern black widow spider, Latrodectus mactans (Araneae, Theridiidae), as a predator of the red imported fire ant, Solenopsis invita (Hymenoptera, Formicidae), in Texas cotton fields. Journal of Applied Entomology 106: 52-57.

Offerman SP, Patrick Daubert G, Clark RF. 2011. The treatment of black widow spider envenomation with antivenin Latrodectus mactans: a case series. The Permanente Journal 15: 76-81.

Orlova EV, Atiqur Rahman M, Gowen B, Volynski KE, Ashton AC, Manser C, van Heel M, Ushkaryov YA. 2000. Structure of $\alpha$-latrotoxin oligomers reveals that divalent cation-dependent tetramers form membrane pores. Nature Structural Biology 7: 48-52.

Rempel JG. 1957. The embryology of the black widow spider, Latrodectus mactans (Fabr.). Canadian Journal of Zoology 35: 35-74.

Ross K, Smith RL. 1979. Aspects of the courtship behavior of the black widow spider, Latrodectus hesperus (Araneae: Theridiidae), with evidence for the existence of a contact sex pheromone. Journal of Arachnology 7: 69-77.

Sherman RP, Groll JM, Gonzalez DI, Aerts MA. 2000. Black widow spider (Latrodectus mactans) envenomation in a term pregnancy. Current Surgery 57: 346-348.

Timms PK, Gibbons RB. 1986. Latrodectism-effects of the black widow spider bite. Western Journal of Medicine 144: 315-317.

Vetter RS. (2013) The brown widow spider, Latrodectus geometricus. The University of California, Riverside. Center for Invasive Species Research. (24 May 2013).

Vetter RS. The prevalence of brown widow and black widow spiders (Araneae: Theridiidae) in urban Southern California. Journal of Medical Entomology 49: 947-951.

Wolfe MD, Myers O, Caravati EM, Rayburn WF, Seifert SA. 2011. Black widow spider envenomation in pregnancy. The Journal of Maternal-Fetal and Neonatal Medicine 24: 122-126.

Zevenbergen JM, Schneider NK, Blackledge TA. 2008. Fine dining or fortress? Functional shifts in spider web architecture by the western black widow Latrodectus hesperus. Animal Behaviour 76: 823-829. 